Research Article

\title{
Impact of Production Inputs and Timing on Crackness of Rice in Northern Ghana
}

\author{
Daniel Asomning Odoom $\left(\mathbb{D},{ }^{1}\right.$ Joseph Xorse Kugbe $\mathbb{D}^{2},{ }^{2}$ Israel Kwame Dzomeku (iD, ${ }^{2}$ \\ Albert Berdjour $\mathbb{D}^{\mathbb{D}},{ }^{3}$ Dennis Owusu Boateng $\mathbb{D}^{1},{ }^{1}$ Richard Naabe Yaro $\mathbb{D},{ }^{2}$ Prince Wireko $\mathbb{D}^{\mathbb{D}},{ }^{1}$ \\ Ebenezer Kofi Sam $\mathbb{D}^{2}{ }^{2}$ and Philip Ghanney $\mathbb{D}^{4}$ \\ ${ }^{1}$ Cocoa Health and Extension Division, Ghana Cocoa Board, Kumasi, Ghana \\ ${ }^{2}$ Faculty of Agriculture, University for Development Studies, Tamale, Ghana \\ ${ }^{3}$ International Institute of Tropical Agriculture (IITA), Tamale, Ghana \\ ${ }^{4}$ College of Resources and Environmental Sciences, Gansu Agricultural University, Lanzhou, China
}

Correspondence should be addressed to Daniel Asomning Odoom; odoom24@gmail.com

Received 22 March 2021; Revised 30 June 2021; Accepted 4 August 2021; Published 17 August 2021

Academic Editor: Vijay Gahlaut

Copyright (C) 2021 Daniel Asomning Odoom et al. This is an open access article distributed under the Creative Commons Attribution License, which permits unrestricted use, distribution, and reproduction in any medium, provided the original work is properly cited.

\begin{abstract}
Under rain-fed conditions, perfumed rice production in Northern Ghana is associated with high paddy cracking during milling. In this study, 4 perfumed rice varieties, 6 staggered planting times, 6 staggered harvesting cycles, and staggered storage duration from harvest to six months of storage were used in a randomized complete block design to identify the best combination of factors that are associated with low cracking in rice production. The experiment was laid out in a randomized complete block design with three geographically distinct locations serving as replicates. Grain moisture and paddy crackness were determined. The results indicated a mixed factorial interaction for all measured variables. Early planting, early harvesting, and short storage duration reduced paddy cracking compared to late treatments $(P<0.05)$. For all treatment combinations, milling within two weeks after harvesting was associated with lower cracking as long as the harvesting cycle did not exceed the fourth cycle. After the second month of storage, percentage cracking was high, approaching $90 \%$ in most cases.
\end{abstract}

\section{Introduction}

Rice is a significant household crop that serves as the main ration for the majority of the world's population and a quarter of the carbohydrate consumed worldwide [1]. Globally, it is the second most important cereal accounting for $27 \%$ of cereal production [2]. The crop provides the basic economic activity for rural households worldwide. Therefore, the production of rice with little breakage, while maintaining the highest possible nutrients, and with cooking attributes has been the main objective of paddy processing companies [3].

High cracking in rice production in Northern Ghana was reported to be associated with many environmental constraints. Paddy therefore needs to be parboiled before milling. The parboiling process enabled the whole milling but led to loss of the aroma, which many consumers in Ghana preferred most [4].
Research has shown that, to attain optimum milling quality as well as high grain yields, paddy must be planted and harvested at accepted physiological maturity [5]. For the rain-fed production system, if the crop is planted too early for harvesting to coincide with the high humidity, the initial growth phase may not get adequate soil moisture for development. When planted late and harvested too early (immature), breakage during milling is high as a result of the high amount of thin, light, unfilled, and chalky kernels that are very fragile. If paddy is harvested very late, breakage during milling is high as a result of a condition referred to as "sun checking," which is the development of fissures in the individual kernels. Knowledge of appropriate timing of planting, harvesting, and storage is therefore pertinent in breakages reduction [6].

The use of appropriate nitrogen application regimes has also been postulated to enhance hardness and reduce 
breakages in rice [7]. Optimum application of nitrogen results in higher yields [8]. Across Northern Ghana, the currently recommended practice is two split applications of nitrogen at the recommended rate. Two split applications have been found to result in inefficient use of nitrogen as most of the nitrogen applied is not available at the grain filling stage when the plant requires the nitrogen nutrient most [9], resulting in less filled grains that are thin, dry out readily, and are susceptible to cracking [10]. Finding an adequate nitrogen application regime for perfumed rice production will therefore result in the production of grains that are well filled and thick to resist easy drying and are resistant to cracking.

Across Northern Ghana, knowledge of the right combination of paddy production systems that enables the production of market-driven perfumed rice that can also be straight-milled in large volumes and under rain-fed conditions is limited [11].

In this paper, field and laboratory experiments were set up to reduce the crackness of paddy, through identification of best varieties, timing of paddy production, nitrogen management, harvesting, and milling in Northern Ghana.

\section{Materials and Methods}

The study is comprised of two components: a field work from planting to harvest and laboratory determination of cracking.

\subsection{Field Location}

2.1.1. Site Description. The field experiment was conducted during the rainy season from April to October 2016 in three geographically distinct rice production locations in the Mamprugu Moagduri District. The district is within longitudes $0.35^{\circ} \mathrm{W}$ and $1.45^{\circ} \mathrm{W}$ and latitude $9.55^{\circ} \mathrm{N}$ and $10.35^{\circ} \mathrm{N}$. The location of the three experimental sites lies in (N $10.17609^{\circ}, \mathrm{W} 001.29434^{\circ}, \quad 140 \mathrm{~m}$ ), (N $10.18252^{\circ}$, $\left.\mathrm{W} 001.29143^{\circ}, 138 \mathrm{~m}\right)$, and ( $10.18249^{\circ}$, W $001.29086^{\circ}$, $140 \mathrm{~m}$ ), respectively. The district shares boundaries with North Gonja, Kumbungu, West Mamprusi, Sissala East, and Builsa South Districts [12].

2.1.2. Soil and Vegetation. Soils in the district are developed under the Savanna vegetation. The soils are quite rich in nutrients especially along the valleys. Alluvial soils, which are also appropriate for rice production, are quite vast around the valleys. In the district, there is significant soil erosion owing to the bad farming methods and widespread bush burning. The natural vegetation is categorized as Guinea Savanna Woodland, which consists of trees of differing dimensions and density, growing over a scattered covering of perennial grasses and shrubs [12].

2.2. Source of Seeds. Four perfume rice foundation seed varieties, namely, Gbewaa, Agra, Exbaika, and Perfume Irrigated, were received from CSIR-Savannah Agricultural Research Institute in Nyankpala.
2.3. Experimental Design and Treatments. The field experiment was a factorial one consisting of $4 \times 6 \times 6: 4$ rice varieties, 6 planting dates, and 6 harvesting cycles. The four rice varieties were combined with six planting times and six harvesting cycles. The six planting times were as follows:

(1) First planting date (first week of July).

(2) Second planting date (second week of July).

(3) Third planting date (third week of July).

(4) Fourth Planting date (fourth week of July).

(5) Fifth planting date (first week of August).

(6) Sixth planting date (second week of August).

The first staggered harvesting was done one (1) week prior to the recommended harvesting date for each variety. Each treatment plot was divided into six subplots. Error due to border effect was reduced by allowing a one (1) meter distance between the subplots. The six subplots were harvested on six harvesting days at one (1) weekly interval.

2.4. Field Preparation and Layout. The field was ploughed and harrowed using a tractor. The experimental field was demarcated and bounded prior to the experimental setup. The bounding was done to block fertilizer drift from one plot to another and also to conserve moisture in the experimental plots. Each experimental plot measured $30 \mathrm{~m} \times 5 \mathrm{~m}$ prior to maturity. One (1) meter alley was left between plots.

2.5. Sowing. A seed rate of $40 \mathrm{~kg} / \mathrm{ha}$ was used for the four (4) perfumed rice varieties: Agra rice, Gbewaa, Exbaika, and Perfume Irrigated, respectively. The seeds were sown in $0.20 \mathrm{~m}$ row spacing and planting distance with a depth of about $2-4 \mathrm{~cm}$. These varieties were sown directly at 1 weekly planting interval for six (6) planting times.

2.6. Weed Management. On the third day after sowing, preemergence herbicide bispyribac sodium $400 \mathrm{~g} / \mathrm{L}$ SC (Bisonrice) was applied to kill all emerging weeds and weed seed stock to avoid early competition during seed emergence and germination. The first manual weeding was done thirty (30) days after sowing and the second manual weeding was done sixty (60) days after sowing.

2.7. Fertilizer Application. Nitrogen, phosphorus (P), and potassium (K) NPK 15:15:15 were applied as basal fertilizer at rates of $120 \mathrm{~kg} / \mathrm{ha} \mathrm{N}, 40 \mathrm{~kg} / \mathrm{ha} \mathrm{P}_{2} \mathrm{O}_{5}$, and $40 \mathrm{~kg} / \mathrm{ha} \mathrm{K}_{2} \mathrm{O}$. Urea was used to top-dress at the rate of $40 \mathrm{~kg} / \mathrm{ha}$.

\subsection{Crack Determination}

2.8.1. Laboratory Location. Laboratory experiment was conducted from October 2016 to May 2017 to determine the level of cracks in the harvested paddy. The laboratory analysis was carried out at the Avnash Rice Mill Laboratory located in Nyankpala. The Avnash Rice Mill is considered to be one of the largest rice milling facilities in Africa. 
Processing of samples was done at two-day intervals and began a day after harvesting (to mimic the possible earliest time for transport of paddy from the field to the milling facility). The crack determination process was repeated for six consecutive months.

2.8.2. Percentage Moisture Content. Grain moisture content was determined using an electronic grain moisture tester (Riceter F Series f 501), which measures and reports moisture content in percentage by weight.

2.8.3. Number of Days of Storage before Milling. This was determined by counting the number of days that grains were stored before milling.

2.8.4. Percentage Paddy Crackness. This was determined by counting the number of cracked paddies and determined as the number of grains with cracks from 100 random paddy grains.

2.8.5. Percentage Cracking with Duration of Storage. This was done by determining the percentage (\%) crackness at a given duration of storage.

2.9. Statistical Analysis. Data were analyzed using GENSTAT statistical package ( $12^{\text {th }}$ edition). Analysis of variance was used and the treatment means were separated using the least significant difference (LSD) at 5\% probability [13].

Correlation between postharvest paddy moisture, duration of storage, and paddy crackness was performed to ascertain the relationships between postharvest conditions and crackness. Where statistically significant correlations existed, linear regression analyses were performed to identify the extent of the relation. Results were presented in tables and graphs.

\section{Results}

3.1. Impact of Production Inputs and Harvest Timing on Percentage Mean Paddy Crackness. Generally, mean paddy crackness was significantly affected $(p<0.05)$ by the interaction of variety, planting date, and harvest cycle. Harvest Cycle 6+ Third Planting + Agra rice variety recorded the highest crackness percentage of 78\%, while Harvest Cycle $6+$ Sixth Planting + Agra rice variety recorded the least cracking percentage of $24 \%$ (Figure 1).

\subsection{Impact of Production Inputs and Timing on Percentage} Paddy Cracking at Harvest. Paddy cracking at harvest was significantly affected $(p<0.05)$ by the interaction of planting date and harvesting cycle.

With the interaction of planting date and harvest cycle, the highest percentage paddy crackness at harvest was recorded by Second Planting + Harvest Cycle 5. It was followed by Second Planting + Harvest Cycle 6, which was at par with Fifth Planting + Harvest Cycle 6. The least percentage paddy crackness at harvest was recorded by First Planting + Harvest Cycle 2. It was followed by First Planting + Harvest Cycle 1, Second Planting + Harvest Cycle 1, Third Planting + Harvest Cycle 1, and Fifth Planting + Harvest Cycle 1, respectively (Figure 2(a)). The sole application of variety also had a significant $(p<0.05)$ influence on paddy crackness at harvest. The Agra variety had the highest paddy crackness at harvest. It was followed by Gbewaa which was at par with Perfume Irrigated. The Exbaika variety recorded the lowest paddy crackness at harvest (Figure 2(b)).

\subsection{Impact of Production Inputs and Timing on Percentage} Paddy Cracking at One Week of Storage. Paddy cracking at 1 week of storage was significantly affected $(p<0.05)$ by the interaction of planting date and harvest cycle as well as the sole application of the two factors.

Second Planting + Harvest Cycle 5 recorded the highest crackness percentage of $72 \%$, while Harvest Cycle $2+$ First Planting had the least cracking percentage of $29 \%$ (Figure 3(a)).

The sole application of variety also had a significant $(p<0.05)$ influence on paddy crackness at harvest. With this, the Agra variety had the highest paddy crackness at harvest. It was followed by Gbewaa which was at par with Perfume Irrigated. Exbaika recorded the lowest paddy crackness at harvest (Figure 3(b)).

\subsection{Impact of Production Inputs and Timing on Percentage} Paddy Cracking at Two Weeks of Storage. Paddy crackness at 2 weeks of storage was significantly affected $(p<0.05)$ by the interaction of planting date, variety, and harvesting cycle.

With this interaction, Agra + Second Planting + Harvest Cycle 5 recorded the highest paddy crackness at two weeks of storage (Figure 4). It was followed by Agra + Third Planting + Harvest Cycle 6 and Gbewaa + Third Planting + Harvest Cycle 6 and was at par with Gbewaa + Sixth Planting + Harvest Cycle 5.

The lowest was recorded by Perfume Irrigated + Third Planting + Harvest Cycle 1. It was followed by Perfume Irrigated + First Planting + Harvest Cycle 1, which was similar to Gbewaa + First Planting + Harvest Cycle 1, Exbaika + First Planting + Harvest Cycle 1, Agra + First Planting + Harvest Cycle 1, and Gbewaa + Second Planting + Harvest Cycle 1.

\subsection{Impact of Production Inputs and Timing on Percentage} Paddy Cracking at One Month of Storage. Paddy crackness at one month of storage was significantly affected $(p<0.05)$ by the interaction of planting date, variety, and harvest cycle.

With this interaction, Agra + Third Planting + Harvest Cycle 5 recorded the highest paddy crackness at one month of storage. It was followed by Gbewaa + Third Planting + Harvest Cycle 6, which was at par with Agra + Third Planting + Harvest Cycle 6, Gbewaa + Sixth Planting + Harvest Cycle 5, and Perfume Irrigated +Second Planting + Harvest Cycle 6. 


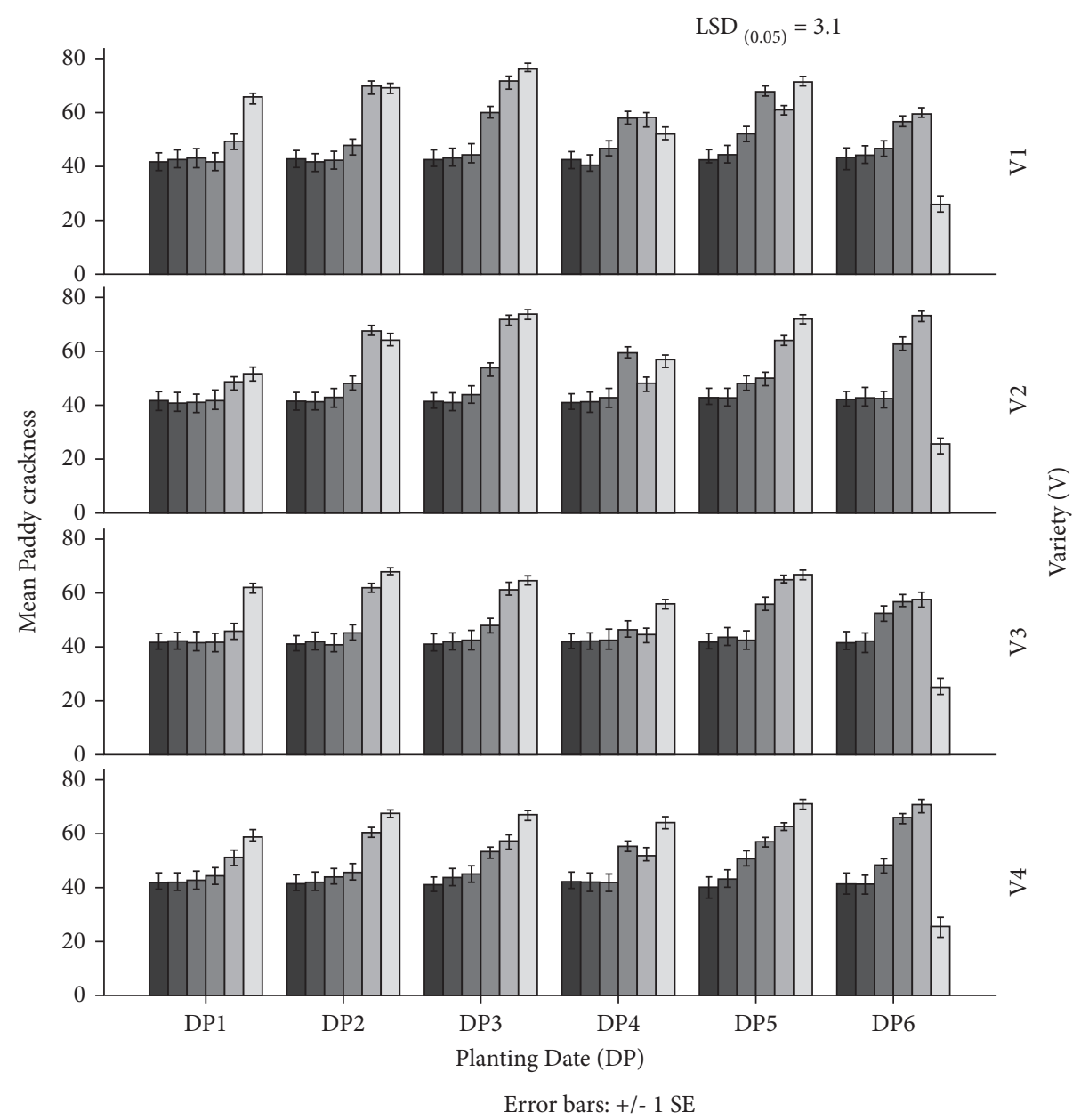

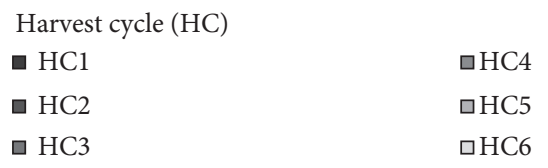

FIGURE 1: Effect of planting date, harvest cycle, and variety on mean paddy cracking in the Northern Savanna Agroecological Zone of Ghana. Bars represent the SEM. DP1 = first planting, DP2 = second planting, DP3 = third planting, DP4 = fourth planting, DP5 = fifth planting, DP6 = sixth planting, V1 = Agra, V2=Gbewaa, V3 = Exbaika, V4= Perfume Irrigated, HC1 = first harvest, HC2 = second harvest, $\mathrm{HC} 3=$ third harvest, $\mathrm{HC} 4=$ fourth harvest, $\mathrm{HC} 5=$ fifth harvest, and HC6 = sixth harvest.

The lowest paddy crackness at one month of storage was recorded by Gbewaa + Fifth Planting + Harvest Cycle 2. It was followed by Exbaika + First Planting + Harvest Cycle 4, Exbaika + Second Planting + Harvest Cycle 2, and Perfume Irrigated + First Planting + Harvest Cycle 1, respectively (Figure 5).

3.6. Impact of Production Inputs and Timing on Percentage Paddy Cracking at Two Months of Storage. Paddy crackness at 2 months of storage was significantly affected $(p<0.05)$ by the interaction of planting date and harvesting cycle and was also affected by variety as the sole factor.

For interaction of planting date and harvest cycle, Third Planting + Harvest Cycle 6 recorded the highest, followed by Fifth Planting + Harvest Cycle 5, Sixth Planting + Harvest
Cycle 6, Sixth Planting + Harvest Cycle 5, and Third Planting + Harvest Cycle 5, respectively. The lowest paddy cracking was recorded by Sixth Planting + Harvest Cycle 1, followed by Third Planting + Harvest Cycle 2 and Second Planting + Harvest Cycle 2 which were at par. It was followed by First Planting + Harvest Cycle 1, Second Planting + Harvest Cycle 1, and Third Planting + Harvest Cycle 1 which were all similar (Figure 6(a)).

With regard to the significant varietal effect, Agra had the highest paddy crackness at harvest. It was followed by Gbewaa which was at par with Perfume Irrigated. Exbaika recorded the lowest paddy crackness at harvest (Figure 6(b)).

3.7. Impact of Production Inputs and Timing on Percentage Paddy Cracking at Three Months of Storage. Paddy crackness at three months of storage was significantly affected 


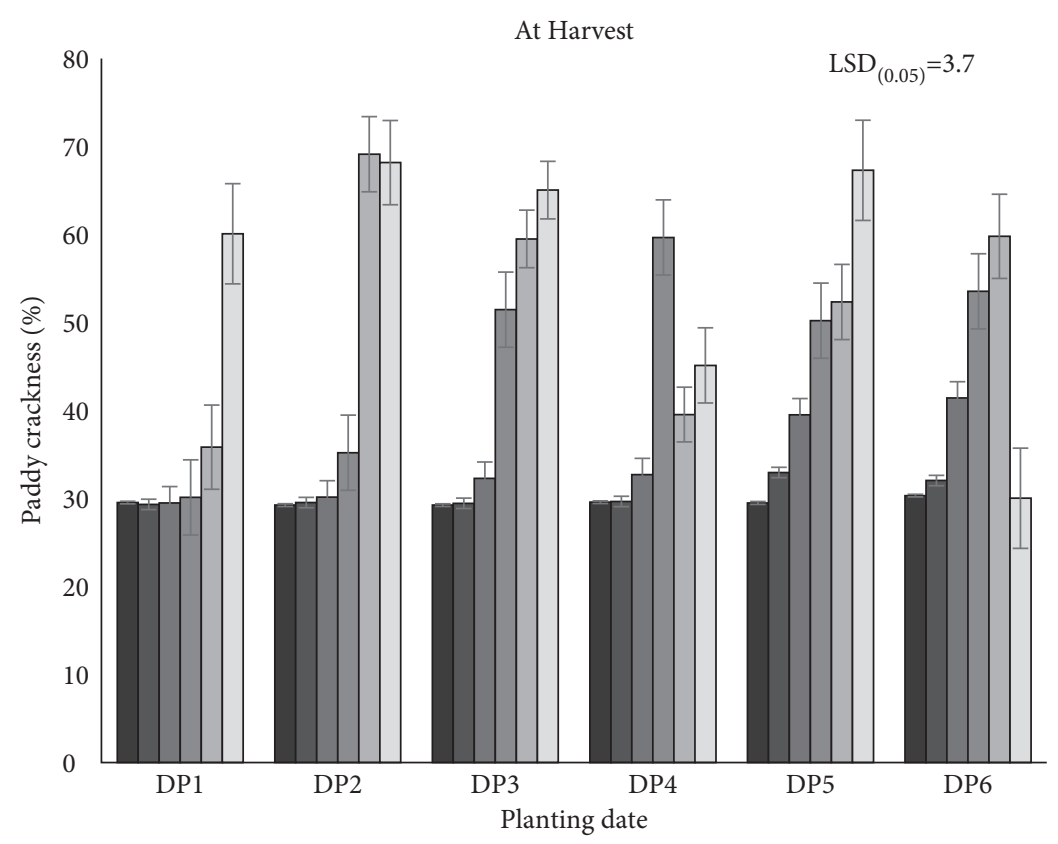
口 $\mathrm{HC} 1$
$\square \mathrm{HC} 4$
$\square \mathrm{HC2}$
$\square \mathrm{HC5}$
口 HC3
$\square$ HC6

(a)

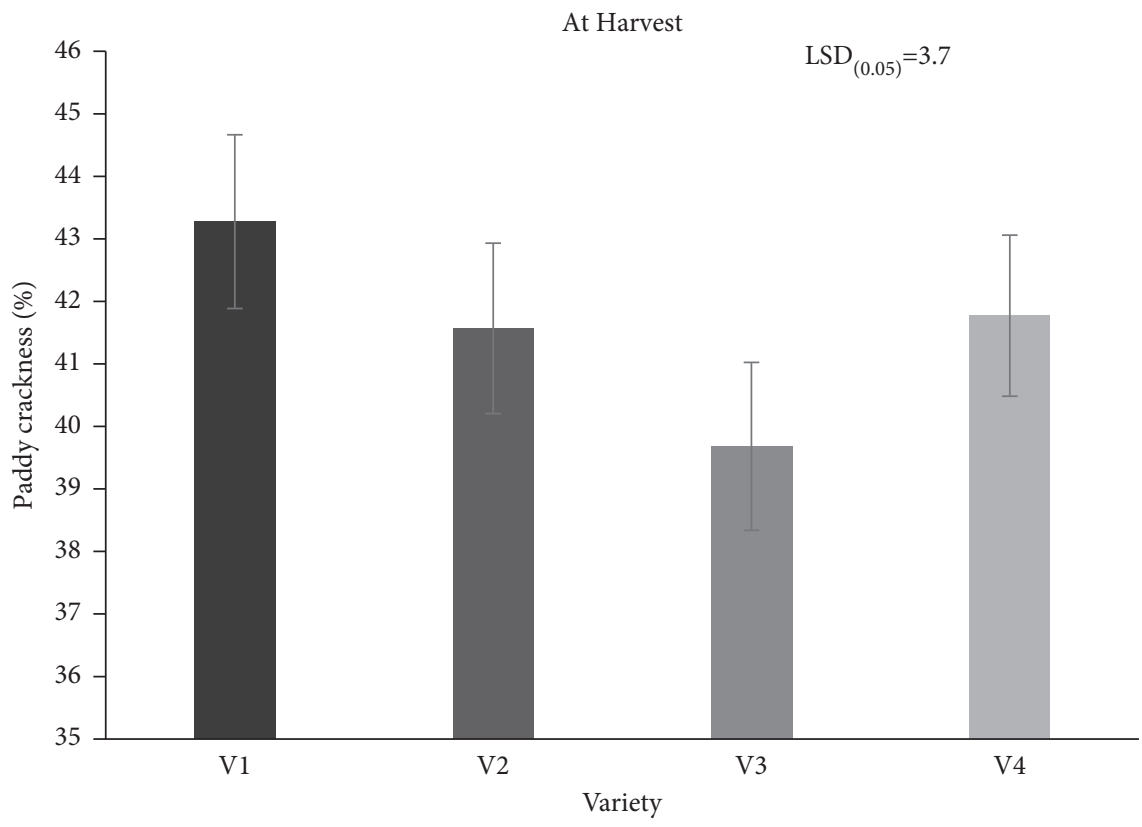

(b)

FIgURE 2: (a) Effect of planting date and harvest cycle on paddy crackness at harvest under rain-fed production systems in the Northern Savanna Agroecological Zone of Ghana. Bars represent the SEM. (b) Effect of perfumed rice varieties on paddy crackness at harvest under rain-fed production systems in the Northern Savanna Agroecological Zone of Ghana. Bars represent the SEM. DP1=first planting, DP2 = second planting, DP3 = third planting, DP4 = fourth planting, DP5 = fifth planting, DP6 = sixth planting, V1= Agra, V2= Gbewaa, V3 = Exbaika, V4 = Perfume Irrigated, HC1 = first harvest, HC2 = second harvest, HC3 = third harvest, HC4 = fourth harvest, HC5 = fifth harvest, and HC6 = sixth harvest. 


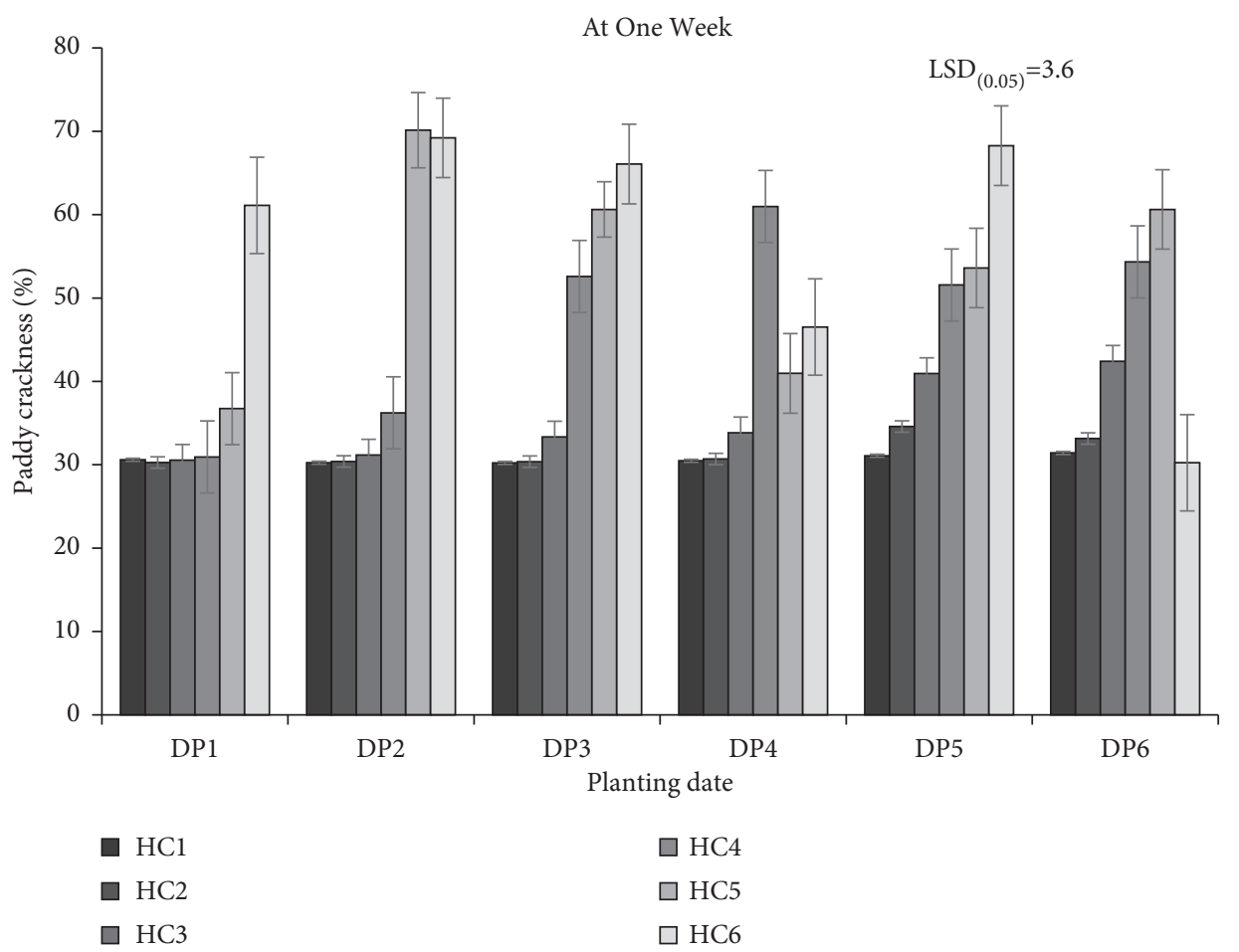

(a)

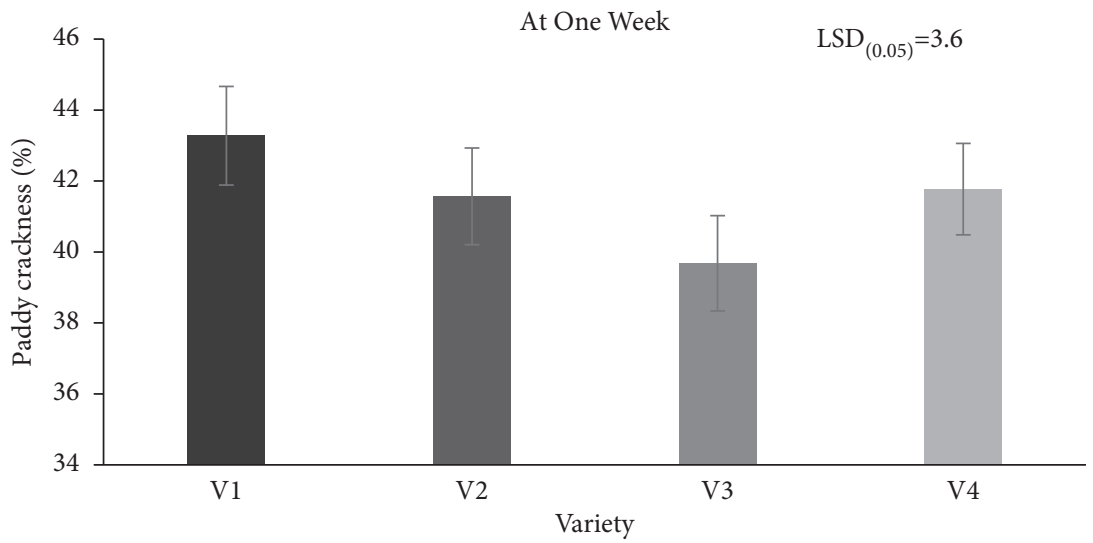

(b)

Figure 3: (a) Effect of planting date and harvest cycle on paddy crackness at one week of storage in the Northern Savanna Agroecological Zone of Ghana. Bars represent the SEM. DP1 = first planting, DP2 = second planting, DP3 = third planting, DP4=fourth planting, DP5 = fifth planting, DP6 = sixth planting, V1=Agra, V2 = Gbewaa, V3 = Exbaika, V4= Perfume Irrigated, HC1=first harvest, $\mathrm{HC} 2=$ second harvest, $\mathrm{HC} 3=$ third harvest, $\mathrm{HC} 4=$ fourth harvest, $\mathrm{HC} 5=$ fifth harvest, and HC6 = sixth harvest. (b) Effect of perfumed rice varieties on paddy crackness at one week of storage under rain-fed production systems in the Northern Savanna Agroecological Zone of Ghana.

$(p<0.05)$ by the interaction of planting date, variety, and harvesting cycle.

With this interaction, Agra + Third Planting + Harvest Cycle 6 recorded the highest paddy crackness at three months of storage. It was followed by Gbewaa + Third Planting + Harvest Cycle 6 and was at par with Agra + Fifth Planting + Harvest Cycle 1, Exbaika + Fifth Planting + Harvest Cycle 2, and Exbaika + Fifth Planting + Harvest Cycle 2 .

The lowest paddy crackness was recorded by Perfume Irrigated + Sixth Planting + Harvest Cycle 6. It was followed by Gbewaa + Sixth Planting + Harvest Cycle 6 and was similar to Exbaika + Sixth Planting + Harvest Cycle 6 and Agra + Sixth Planting + Harvest Cycle 6 (Figure 7).

\subsection{Impact of Production Inputs and Timing on Percentage} Paddy Cracking at Four Months of Storage. Paddy crackness at 4 months of storage was significantly affected $(p<0.05)$ by the interaction of planting date and harvesting cycle.

With this interaction, Sixth Planting + Harvest Cycle 5 had the highest paddy crackness. It was followed by Third 


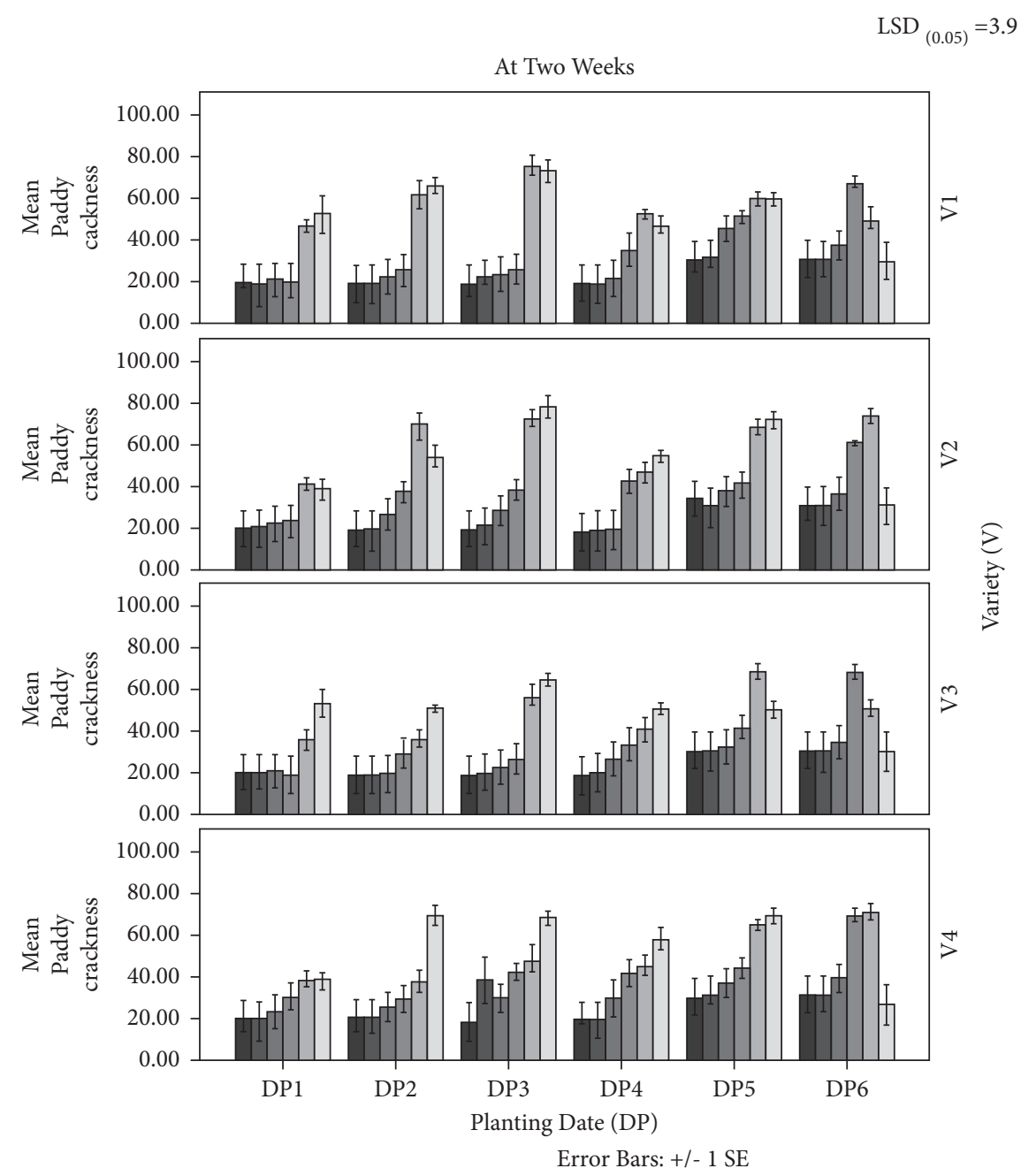

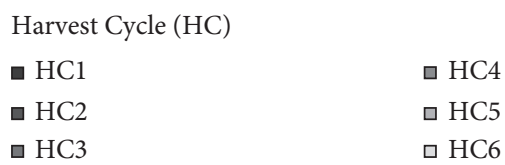

Figure 4: Effect of planting date, variety, and harvest cycle on paddy crackness at two weeks of storage in the Northern Savanna Agroecological Zone of Ghana. Bars represent the SEM. DP1 = first planting, DP2 $=$ second planting, DP3 = third planting, DP4 $=$ fourth planting, DP5 = fifth planting, DP6 = sixth planting, V1 = Agra, V2 = Gbewaa, V3 = Exbaika, V4= Perfume Irrigated, HC1 = first harvest, $\mathrm{HC} 2=$ second harvest, $\mathrm{HC} 3=$ third harvest, $\mathrm{HC} 4=$ fourth harvest, $\mathrm{HC} 5=$ fifth harvest, and $\mathrm{HC} 6=$ sixth harvest.

Planting + Harvest Cycle 4, Fourth Planting + Harvest Cycle 3, Sixth Planting + Harvest Cycle 3, Sixth Planting + Harvest Cycle 3, Fourth Planting + Harvest Cycle 6, and First Planting + Harvest Cycle 5, which were all at par.

The lowest was recorded by Sixth Planting + Harvest Cycle 6. It was followed by Fifth Planting + Harvest Cycle 3, Third Planting + Harvest Cycle 1, which was at par with First Planting + Harvest Cycle 1, and Fourth Planting + Harvest Cycle 2 (Figure 8).

\subsection{Impact of Production Inputs and Timing on Percentage} Paddy Cracking at Five Months of Storage. Paddy crackness at 5 months of storage was significantly affected $(p<0.05)$ by the interaction of planting date and harvesting cycle.
With this, planting date 6 and harvest cycle 1 recorded the highest crackness percentage of $75 \%$, while planting date 6 and harvest cycle 6 had the least cracking percentage of $30 \%$. The highest cracking was followed by Fourth Planting + Harvest Cycle 3, which was at par with Third Planting + Harvest Cycle 3, Third Planting + Harvest Cycle 4, Second Planting + Harvest Cycle 2, Fourth Planting + Harvest Cycle 6, and Fifth Planting + Harvest Cycle 6.

The lowest paddy crackness at the fifth month of storage was recorded by Sixth Planting + Harvest Cycle 6. It was followed by Second Planting + Harvest Cycle 5, Fifth Planting + Harvest Cycle 2, Sixth Planting + Harvest Cycle 2, and Second Planting + Harvest Cycle 1, which were all at par (Figure 9). 


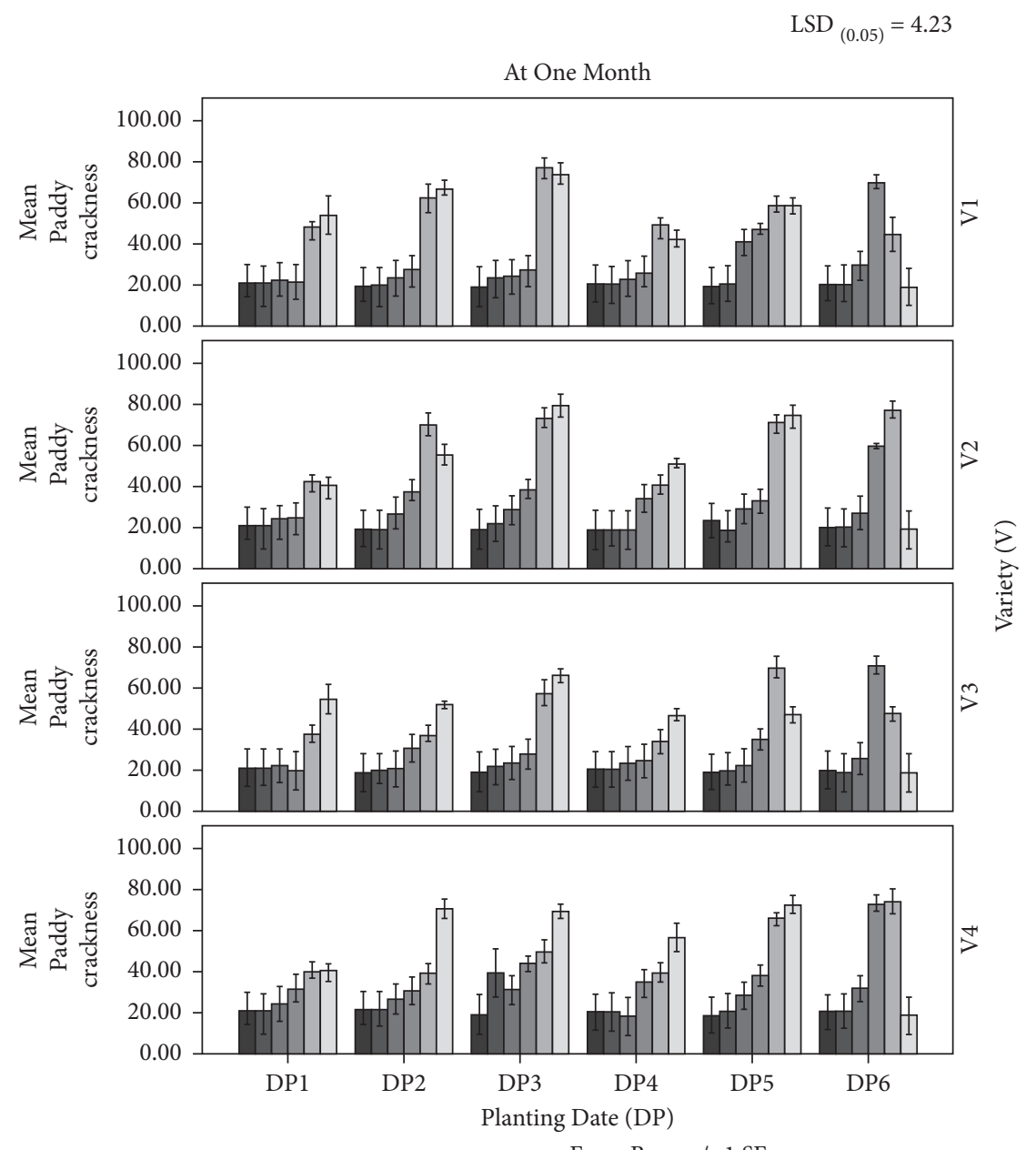

Harvest Cycle (HC)

$\begin{array}{ll}\square \mathrm{HC} 1 & \text { 口 HC4 } \\ \square \mathrm{HC2} & \text { 口 HC5 } \\ \square \mathrm{HC} 3 & \text { 口 HC6 }\end{array}$

Figure 5: Effect of planting date, variety, and harvest cycle on paddy crackness at one month of storage in the Northern Savanna Agroecological Zone of Ghana. Bars represent the SEM. DP1 = first planting, DP2 = second planting, DP $3=$ third planting, DP4 = fourth planting, DP5 = fifth planting, DP6 = sixth planting, V1 = Agra, V2 = Gbewaa, V3 = Exbaika, V4 = Perfume Irrigated, HC1 = first harvest, $\mathrm{HC} 2=$ second harvest, $\mathrm{HC} 3=$ third harvest, $\mathrm{HC} 4=$ fourth harvest, $\mathrm{HC} 5=$ fifth harvest, and $\mathrm{HC} 6=$ sixth harvest.

\subsection{Impact of Production Inputs and Timing on Percentage} Paddy Cracking at Six Months of Storage. Paddy crackness at 6 months of storage was significantly affected $(p<0.05)$ by the interaction of planting date and harvesting cycle.

Planting date 5 and harvest cycle 6 recorded the highest crackness percentage of 74\%, while planting date 6 and harvest cycle 6 had the least cracking percentage of 30\%. The treatment with the highest crackness levels was followed by Second Planting + Harvest Cycle 4, Fifth Planting + Harvest Cycle 3, Third Planting + Harvest Cycle 5, Fourth Planting + Harvest Cycle 2, and First Planting + Harvest Cycle 4, respectively.

The lowest was recorded by Sixth Planting + Harvest Cycle 6. It was followed by First Planting + Harvest Cycle 3, Third Planting + Harvest Cycle 3, Sixth Planting + Harvest Cycle 2, Sixth Planting + Harvest Cycle 3, and First Planting + Harvest Cycle 1, respectively (Figure 10).
3.11. Impact of Planting Time, Harvest Time, and Storage Duration on Percentage Paddy Cracking. Paddy cracking was significantly affected $(p<0.05)$ by the interaction of planting date, harvesting cycle, and storage duration. First Planting through to Third Planting + First to Third Harvest Cycle + First Harvest to 2 Months of Storage consistently recorded the lowest paddy cracking of $17-20 \%$. The highest paddy cracking was recorded by Fourth Planting + Harvest Cycle $6+6$ Months of Storage. It was followed by Third Planting + Harvest Cycle $6+6$ Months of Storage, which was at par with Sixth Planting + Harvest Cycle 3+5 Months of Storage, Sixth Planting + Harvest Cycle $4+6$ Months of Storage, and Fifth Planting + Harvest Cycle $4+5$ Months of Storage, respectively.

Early planting and early harvesting and low storage duration tended to reduce paddy cracking. In contrast, late 


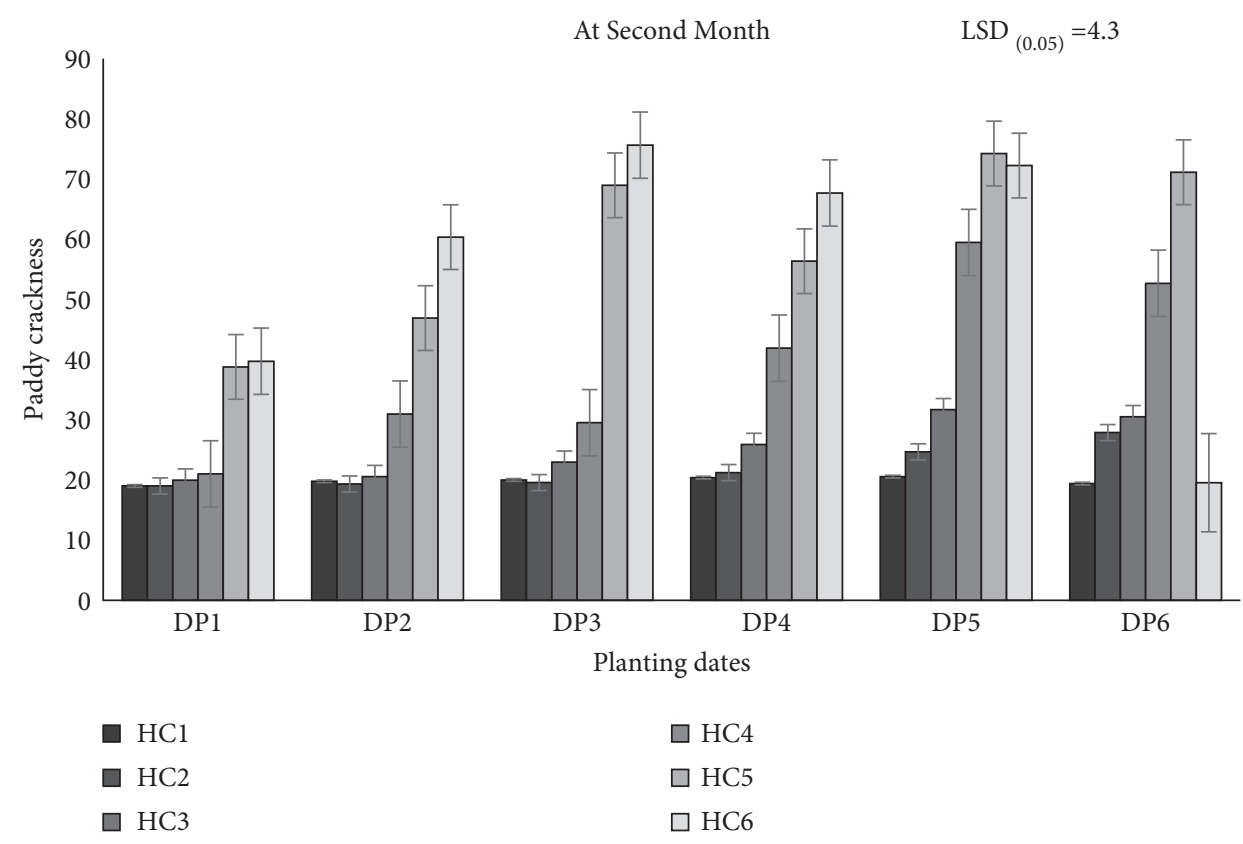

(a)

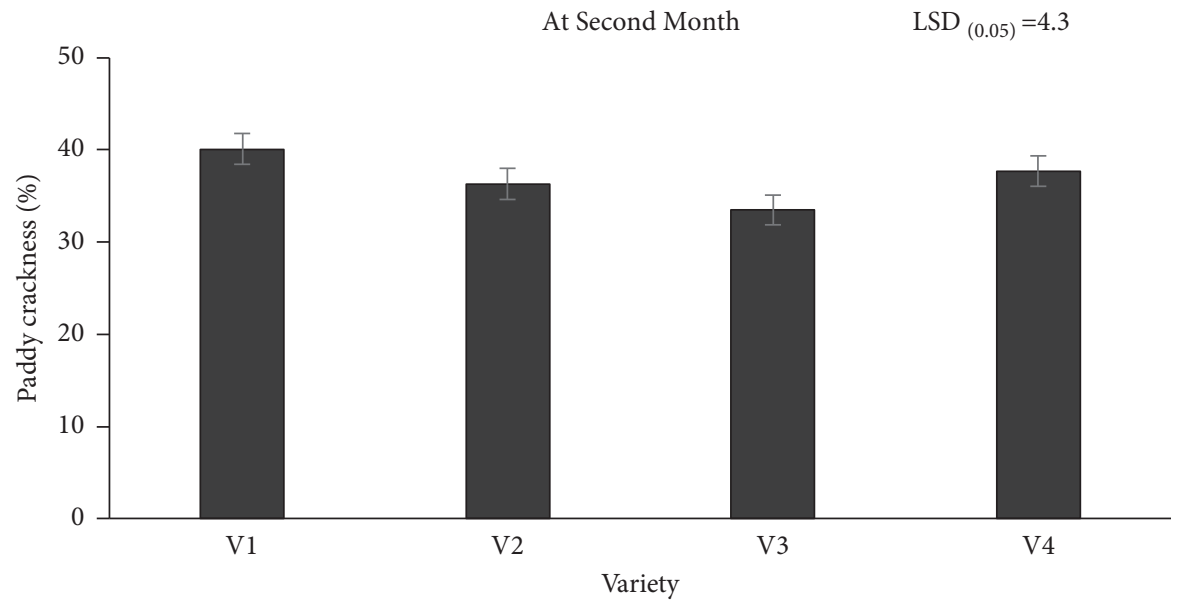

(b)

Figure 6: (a) Effect of planting date and harvest cycle on paddy crackness at two months of storage in the Northern Savanna Agroecological Zone of Ghana. Bars represent the SEM. (b) Effect of perfumed rice varieties on paddy crackness at two months of storage in the Northern Savanna Agroecological Zone of Ghana. Bars represent the SEM. DP1 = first planting, DP2 = second planting, DP3=third planting, DP4 = fourth planting, DP5 = fifth planting, DP6 = sixth planting, V1= Agra, V2= Gbewaa, V3 = Exbaika, V4= Perfume Irrigated, $\mathrm{HC} 1=$ first harvest, $\mathrm{HC} 2=$ second harvest, $\mathrm{HC} 3=$ third harvest, $\mathrm{HC} 4=$ fourth harvest, $\mathrm{HC} 5=$ fifth harvest, and HC6 = sixth harvest.

planting, late harvesting, and extended duration of storage tended to result in high paddy cracking (Figure 11).

\subsection{Pearson's Correlation Matrix and Model Fit Parameters} between Grain Moisture, Duration of Storage, and Paddy Crackness. The correlation analysis of data taken showed that grain moisture at milling had strong negative relationship with paddy crackness $\left(R^{2}=-0.3429 ; p<0.001\right)$. However, storage duration was observed to have a strong positive relationship with paddy crackness $\left(R^{2}=0.4194\right.$; $p<0.001)$.

The regression equations for all the significant relationships observed in Table 1 are provided in Table 2. Paddy crackness had $R^{2}$ values of 0.117 and 0.176 with its relationship with grain moisture and storage duration, respectively. This implies that $11.7 \%$ and $17.6 \%$ of the changes in paddy crackness can be explained by the changes in grain moisture and storage duration, respectively. 


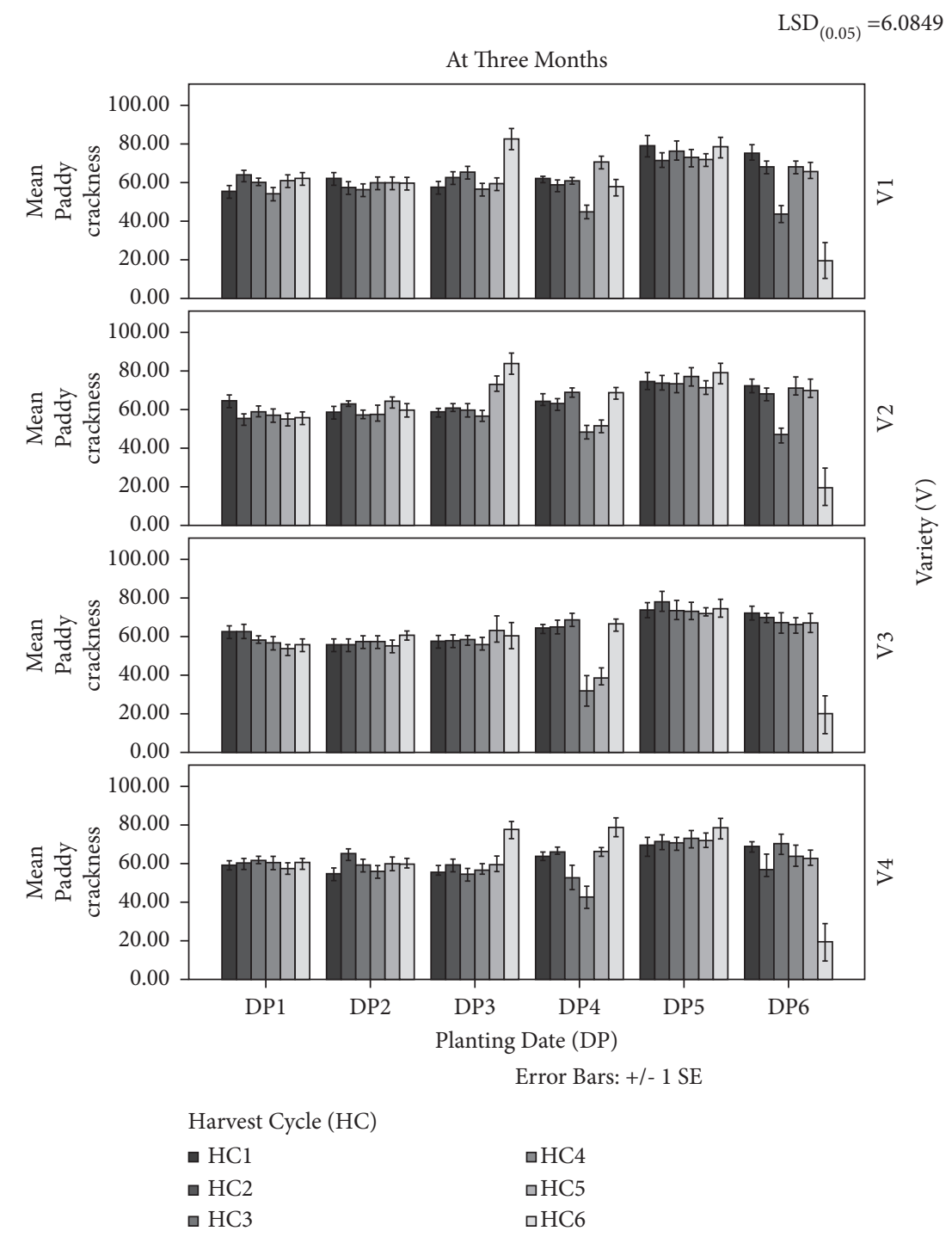

FiguRE 7: Effect of planting date, variety, and harvest cycle on paddy crackness at three months of storage in the Northern Savanna Agroecological Zone of Ghana. Bars represent the SEM. DP1 = first planting, DP2 = second planting, DP3 = third planting, DP4 = fourth planting, DP5 = fifth planting, DP6 = sixth planting, V1 = Agra, V2 = Gbewaa, V3 = Exbaika, V4 = Perfume Irrigated, HC1 = first harvest, $\mathrm{HC} 2=$ second harvest, $\mathrm{HC} 3=$ third harvest, $\mathrm{HC} 4=$ fourth harvest, $\mathrm{HC} 5=$ fifth harvest, and HC6 = sixth harvest.

\section{Discussion}

Significantly interactive effect $(p<0.05)$ of variety, planting date, and harvest cycle shows that variety, planting date, and harvest time are parameters that determine crackness at the time of harvest. The existence of different shapes and sizes of grains, together with different growth conditions between planting time and harvest, must have differently combined to affect cracking. Generally, for any variety planted at a recommended fertilizer application, crackness increased in late planting and late harvesting due to unavailable moisture during plant growth, flowering, and yielding. Harvesting after Harvest Cycle 3 was associated with high cracking and must be avoided. The time of harvest appears to be the most critical factor that determines cracking. Apart from Sixth Planting and Harvest Cycle 6, which recorded an unexplainably low cracking, cracking in paddy generally increased with delayed planting and delayed harvesting. In contrast, early planting and early harvesting reduced grain cracking. Perfumed irrigated variety, planted at fourth planting and for all harvesting cycles consistently, had lower percentage cracking except for Harvest Cycle 6. As also noted by [14], late harvesting is associated with high cracks due to the incidence of natural senescence. The authors in [15] used the incidence of moisture differentials to illustrate the phenomenon of crack induction. Through Moisture Readsorption by Field Rice Grains, when rice grains in the field reach harvest moisture (22\%), the field sample may contain grains with moisture contents (MC) between 15 and $45 \%$. Many individual grains may dry to below 15\% MC during the day. Such grains can fissure on the stalk when they reabsorb moisture at night. Through Rapid Drying (to near storage moisture), rapid drying produces a steep moisture gradient in the grain. As this gradient reclines after 


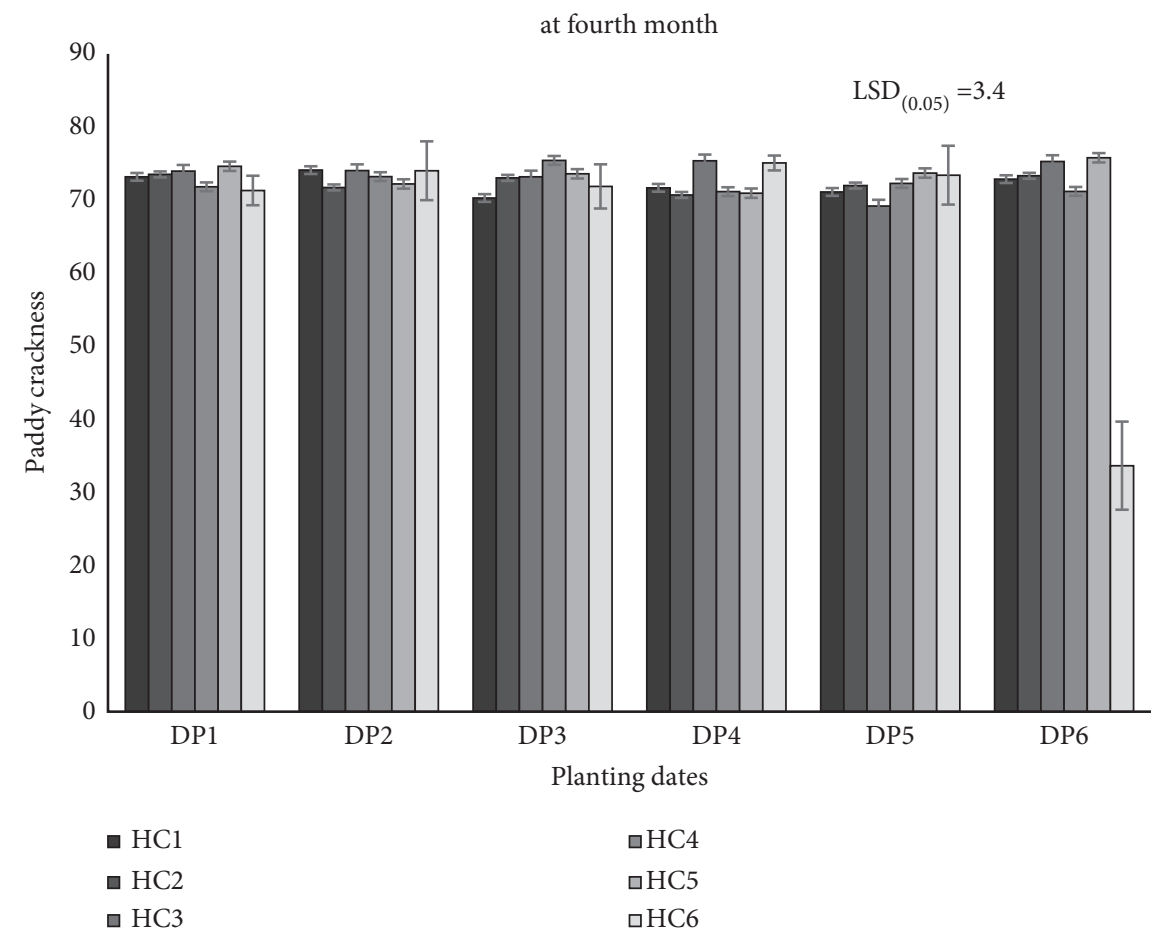

Figure 8: Effect of planting date and harvest cycle on paddy cracking at four months of storage in the Northern Savanna Agroecological Zone of Ghana. Bars represent the SEM. DP1 = first planting, DP2= second planting, DP3 = third planting, DP4=fourth planting, DP5 = fifth planting, DP6 = sixth planting, V1=Agra, V2=Gbewaa, V3 = Exbaika, V4= Perfume Irrigated, HC1=first harvest, $\mathrm{HC} 2=$ second harvest, $\mathrm{HC} 3=$ third harvest, $\mathrm{HC} 4=$ fourth harvest, $\mathrm{HC} 5=$ fifth harvest, and HC6 = sixth harvest.

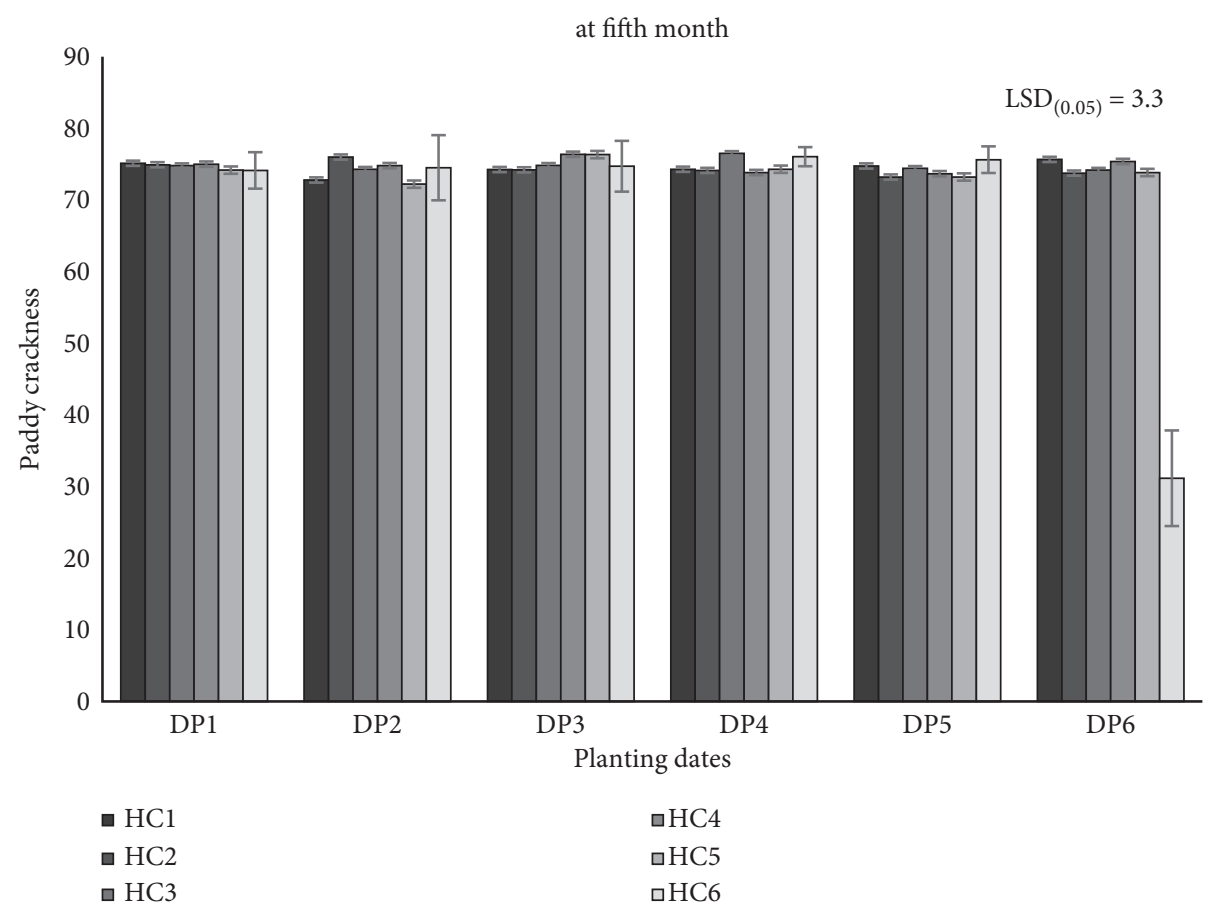

Figure 9: Effect of planting date and harvest cycle on paddy crackness at five months of storage in the Northern Savanna Agroecological Zone of Ghana. Bars represent the SEM. DP1 = first planting, DP2 = second planting, DP3 = third planting, DP4=fourth planting, DP5 = fifth planting, DP6 = sixth planting, V1=Agra, V2 = Gbewaa, V3 = Exbaika, V4= Perfume Irrigated, HC1 = first harvest, $\mathrm{HC} 2=$ second harvest, $\mathrm{HC} 3=$ third harvest, $\mathrm{HC} 4=$ fourth harvest, $\mathrm{HC} 5=$ fifth harvest, and $\mathrm{HC} 6=$ sixth harvest. 


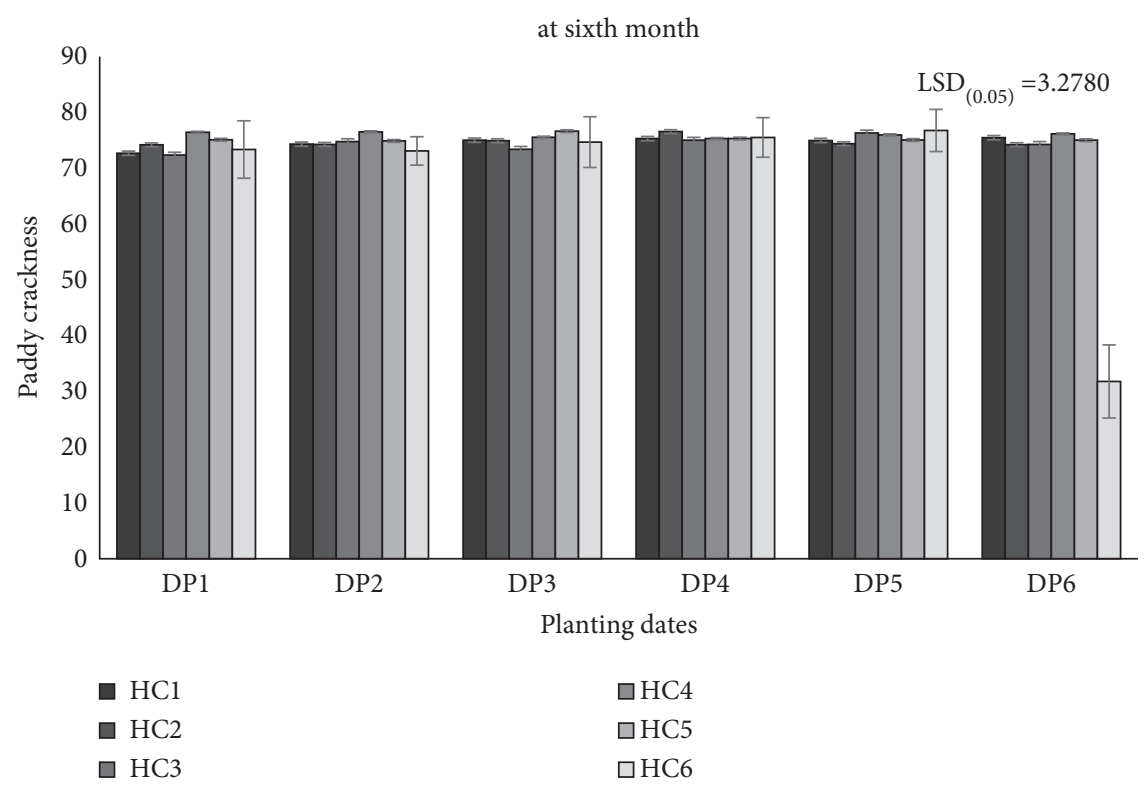

Figure 10: Effect of planting date and harvest cycle on paddy cracking at six months of storage in the Northern Savanna Agroecological Zone of Ghana. Bars represent the SEM. DP1 = first planting, DP2= second planting, DP3 = third planting, DP4=fourth planting, DP5 = fifth planting, DP6 = sixth planting, V1 = Agra, V2=Gbewaa, V3= Exbaika, V4= Perfume Irrigated, HC1=first harvest, $\mathrm{HC} 2=$ second harvest, $\mathrm{HC} 3=$ third harvest, $\mathrm{HC} 4=$ fourth harvest, $\mathrm{HC} 5=$ fifth harvest, and $\mathrm{HC} 6=$ sixth harvest.

drying, the grain surface receives moisture from the interior and expands while the grain interior loses moisture and contracts. As this combination of stresses (compressive at the surface and tensile at the center) develops with time, the grain fails in tension by pulling itself apart at its center. The rheological aspects (stress, strain, and time) cause the grain failure and cracking.

At a given storage time, the date of planting and harvest time impact paddy cracking due to the grain desiccation and fissuring phenomenon. Similar reasoning holds for the observed impact of planting date, harvest cycle, and duration of storage on cracking. Earlier harvesting coincides with a high relative humidity that slows the drying process.

Slow drying of paddy is recommended to reduce cracking of rice $[4,16]$. However, the harsh harmattan condition associated with late harvesting in the northern region of Ghana at the time of harvest and storage $[17,18]$ comes with it rapid desiccation of the prevailing environment that hastens drying and facilitates the incidence of desiccation, fissuring, and cracking.

The longer the paddy remains on the field, the longer the effect of the desiccation on the paddy and the higher the incidence of cracking. The multi-impact of natural senescence and rapid desiccation on rice cracking makes the time of harvesting an important determinant of cracking in Northern Ghana. The higher the duration of storage of rice, the higher the incidence of cracking. The observed trend of impact of time of storage on crackness is in consonance with reports from other researchers [4]. The observed cracking trend can be attributed to the combination of senescence and moisture stress and differential strain difference during storage. As noted by [15], through Moisture Readsorption by Dry Rice Grains, rice is hygroscopic; the low-moisture (dried) grain reabsorbs moisture from any source to which it is exposed. Moisture adsorbed through the grain surface causes the starch cells to expand and produce compressive stresses. Since the grain is a "free body," compressive stresses are countered by equal but opposite tensile stresses at the grain center. When the compressive stresses at the surface exceed the tensile strength of the grain at its center, a fissure develops. Fissured grains usually break during milling. The sources of the grain moisture during storage range from adsorption of vapor at night and losses during the day, while the grains are in storage. 

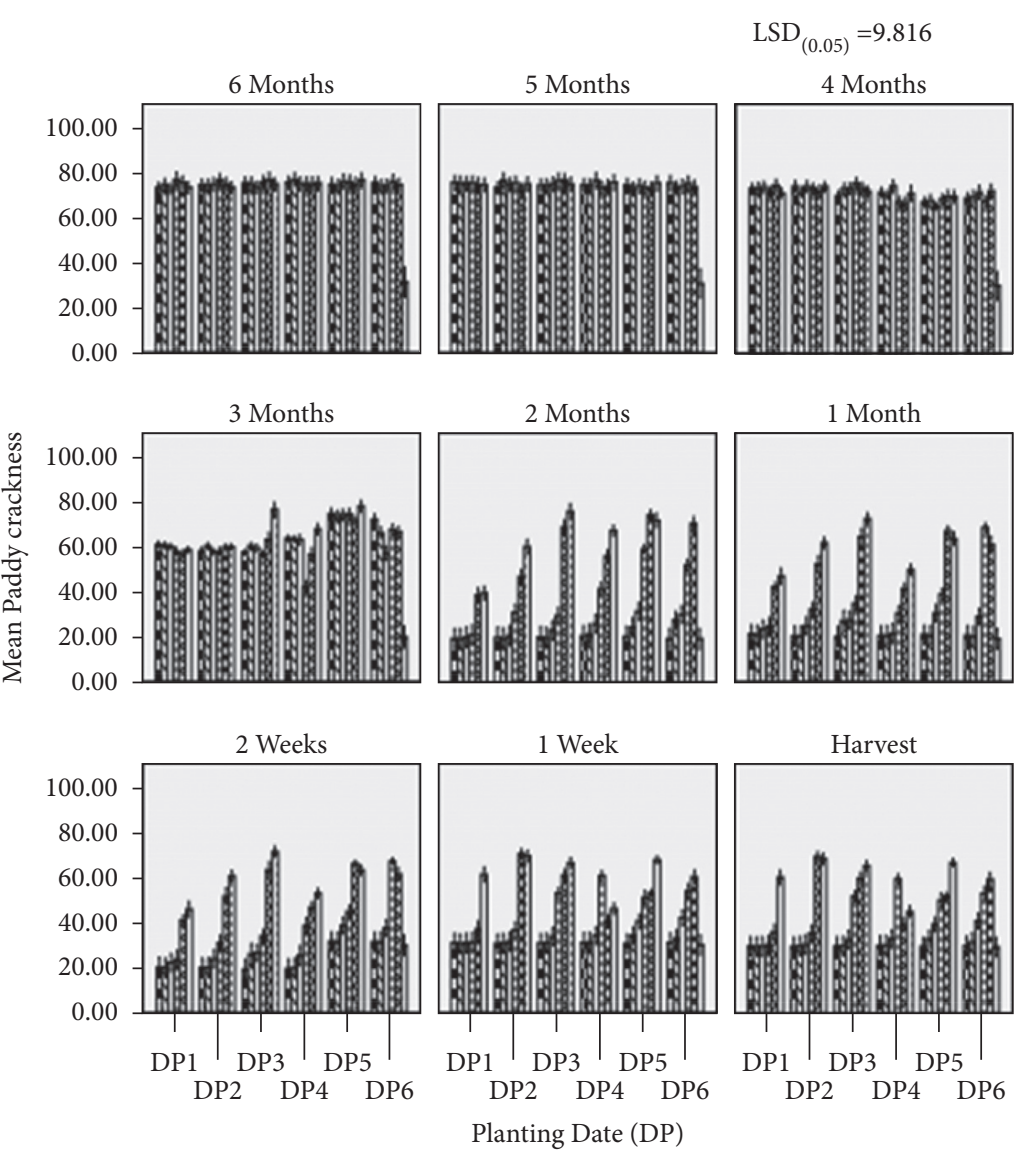

Error Bars: +/- $1 \mathrm{SE}$

Harvest Cycle (HC)

\begin{tabular}{|c|c|}
\hline HC1 & 柬 $\mathrm{HC} 4$ \\
\hline $\mathbb{N}$ HC2 & 엉 HC5 \\
\hline 血 HC3 & 口 HC6 \\
\hline
\end{tabular}

FIgURE 11: Effect of planting date, harvest cycle, and storage duration on mean paddy cracking in the Northern Savanna Agroecological Zone of Ghana. Bars represent the SEM. DP1 = first planting, DP2 = second planting, DP3 = third planting, DP4=fourth planting, DP5 = fifth planting, DP6 = sixth planting, V1 = Agra, V2=Gbewaa, V3 = Exbaika, V4= Perfume Irrigated, HC1=first harvest, $\mathrm{HC} 2=$ second harvest, $\mathrm{HC} 3=$ third harvest, $\mathrm{HC} 4=$ fourth harvest, $\mathrm{HC} 5=$ fifth harvest, and $\mathrm{HC} 6=$ sixth harvest.

TABLE 1: Pearson's correlation matrix between paddy crackness, grain moisture (GM), and duration of storage (SD). Values are coefficient.

\begin{tabular}{lc}
\hline Parameters & PC \\
\hline GM & $-0.3429^{* *}$ \\
SD & $0.4194^{* *}$ \\
\hline
\end{tabular}

$\mathrm{SD}=$ storage duration, $\mathrm{GM}=$ grain moisture, $\mathrm{PC}=$ paddy crackness, ** = significant at $p<0.01$, and ${ }^{* *}=$ significant at $p<0.05$.

TABLE 2: Linear regressions and model fit parameters for statistically correlated $(p<0.05)$ parameters and duration of storage on paddy crackness.

\begin{tabular}{lccc}
\hline Relation & $R^{2}$ & SEE & Significance level \\
\hline $\mathrm{PC}=44.41-1.2666(\mathrm{GM})$ & 0.117 & 28.4 & $<0.001$ \\
$\mathrm{PC}=4.7924(\mathrm{SD})+28.78$ & 0.176 & 26.1 & $<0.001$ \\
\hline
\end{tabular}

$\mathrm{GM}=$ grain moisture, $\mathrm{PC}=$ paddy crackness, $\mathrm{SD}=$ storage duration, $\mathrm{SEE}=$ standard error of the estimate, and $R^{2}=$ coefficient of determination.

\section{Conclusion}

Paddy cracking in aromatic rice production systems is affected by variety, time of planting, harvesting time, and duration of storage. Different varieties resist cracking at different levels depending on the date of planting, date of harvesting, and storage duration. However, the Exbaika variety favors low cracking due to its relative bulkiness that makes it more resistant to fissures. For all treatment combinations, milling within two months after harvesting is associated with lower cracking as long as the harvesting cycle does not exceed the fourth cycle. Within the first to the third harvesting cycle, therefore, crackness is low for combinations of treatments within the first month of crack determination. After the second month of storage, the percentage of crackness was high and approaching ninety percent (90\%). Extended storage duration above the third month resulted in the highest cracking of paddy due to extended 
intermittent desiccation and remoisturization that enhances differential stresses and grains and facilitates cracking. To reduce cracking, harvesting must be done at maturity.

\section{Data Availability}

The data will be made available from the corresponding author upon request (odoom24@gmail.com).

\section{Conflicts of Interest}

The authors declare that they have no conflicts of interest.

\section{References}

[1] M. Kubo and M. Purevdorj, "The future of rice production and consumption," Journal of Food Distribution Research, vol. 35, pp. 128-142, 2004.

[2] B. Cottyn, E. Regalado, B. Lanoot, M. De Cleene, T. W. Mew, and J. Swings, "Bacterial populations associated with rice seed in the tropical environment," Phytopathology, vol. 91, no. 3, pp. 282-292, 2001.

[3] M. Addison, P. Sarfo-Mensah, and S. E. Edusah, "Assessing Ghana's initiative of increasing domestic rice production through the development of rice value chain," Global Journal of Agricultural Economics Extension and Rural Development, vol. 3, no. 4, pp. 230-237, 2015.

[4] J. O. Akowuah, A. Addo, and A. Bart-Plange, "Influence of drying temperature and storage duration on fissuring and milling quality of jasmine 85 rice variety," Journal of Science and Technology, vol. 32, pp. 26-33, 2012.

[5] A. C. Kumoro, D. R. Lukiwati, D. R. Praseptiangga et al., "Effect of drying and milling modes on the quality of white rice of an Indonesian long grain rice cultivar," Acta Scientiarium Polonorium, Technologia Alimentaria, vol. 18, no. 2, pp. 195-203, 2019.

[6] M. Y. Ali, S. M. A. Hossain, S. M. A. Ahmed, and M. A. Gaffer, "Effects of harvesting time on seed and seed quality of transplanted aman rice varieties," Blangladesh Journal of Crop Science, vol. 11, pp. 7-12, 2000.

[7] F. Faraji, M. Esfahani, M. Kavousi, M. Hahvi, and A. Forghani, "Effect of nitrogen fertilizer levels on Fe and protein content, grain breakage and grain yield of rice (Oryza sativa L. cv. khazar)," Biharean Biologist, vol. 7, no. 1, pp. 25-28, 2013.

[8] S. Firouzi, "Grain, milling, and head rice yields as affected by nitrogen rate and bio-fertilizer application," Acta Agriculturae Slovenica, vol. 105, no. 2, pp. 241-248, 2015.

[9] D. B. Tari and E. Amiri, "Determination of nitrogen use efficiency and yield of rice at different nitrogen fertilization treatments in irrigated lowland," Good Manufacturing Practice Review, vol. 17, pp. 308-317, 2015.

[10] H. U. Rehman, S. M. A. Basra, and A. Wahid, "Optimizing nitrogen-split application time to improve dry matter accumulation and yield in dry direct seeded rice," International Journal of Agriculture and Biology, vol. 15, pp. 41-47, 2013.

[11] B. T. Anang, "Microcredit, production systems and technical efficiency of smallholder rice production in Northern Ghana," Doctoral Thesis, University of Helsinki, Helsinki, Finland, 2017.

[12] MOFA, Agriculture in Ghana: Facts and Figures, Policy Planning Unit, Monitoring and Evaluation Department, Ministry of Food and Agriculture, Accra, Ghana, 2010.
[13] R. G. D. Steel and J. H. Torrie, Principles and Procedures of Statistics: A Biometrical Approach, McGraw-Hill, New York, NY, USA, 1980.

[14] S. Firouzi and M. R. Alizadeh, "An investigation of the effects of harvesting time and milling moisture content of paddy on the quality of milled rice," International Journal of Bioscience, vol. 3, no. 10, pp. 133-138, 2013.

[15] O. R. Kunze, "Effect of drying on grain quality-moisture readsorption causes fissured rice grains," Agricultural Engineering International: The CIGR Ejournal, vol. X, no. 1, 2005.

[16] J. F. Thompson, J. Knutson, and B. Jenkins, "Effect of weather and rice moisture at harvest on milling quality of California medium-grain rice," American Society of Agricultural and Biological Engineers, vol. 49, no. 2, pp. 435-440, 1990.

[17] M. Oteng-Ababio, S. Mariwah, and L. Kusi, "Is the underdevelopment of northern Ghana a case of environmental determinism or governance crisis?" Ghana Journal of Geography, vol. 9, pp. 5-39, 2017.

[18] M. Padi, "Weather transition periods in Ghana," Journal of Climatology and Weather Forecasting, vol. 5, no. 2, p. 211, 2017. 